\title{
AUTOMOTIVE MAINTENANCE QUALITY OF SERVICE INFLUENCING FACTORS
}

\author{
Dragana Velimirović, Čedomir Duboka, Predrag Damnjanović
}

Original scientific paper

Large majority of manufacturers, and among them car manufacturers are the most typical example, recognize more and more the importance of after-sales activities, implementing them into the company core business offer. Automotive maintenance is one of them. The reasons are manifold and to achieve them they need to primarily ensure the high quality of those services. This was the basic reason for initiating the research presented in this work, whose main objective was to define quality factors for assessment of after-sales services in automotive business activities. The paper presents the procedure and the accomplished results of the research. Nine quality factors have been defined and their significance was determined. It is believed that these results could facilitate automotive service station management, since it would primarily analyze and improve those segments that were assessed by users as the most significant.

Keywords: after-sales services; automotive maintenance; quality factors; quality of service

Utjecajni faktori uporabne kvalitete održavanja vozila

Izvorni znanstveni članak Mnogi proizvođači danas, a među njima proizvođači automobila kao tipičan primjer, uviđaju značaj postprodajnih usluga i implementiraju ih u svoju osnovnu ponudu. Održavanje vozila je primjer ovih usluga. Razlozi su višestruki, a da bi se oni postigli potrebno je da se prvenstveno osigura njihova visoka kvaliteta. Upravo iz tog razloga je pokrenuto istraživanje prikazano u ovom radu čiji je osnovni cilj bio da se utvrde faktori kvalitete postprodajnih usluga u automobilskoj industriji. U radu je prikazan postupak i rezultati istraživanja, imenovano je devet faktora kvalitete i utvrđena je njihova značajnost. Smatra se da bi ovi rezultati mogli olakšati upravljanje kvalitetom usluga u autoservisima, jer bi rukovodstvo prvenstveno analiziralo i unapređivalo one segmente koje su korisnici procijenili kao najznačajnije.

Ključne riječi: faktori kvalitete; održavanje vozila; postprodajne usluge; uporabna kvaliteta

\section{Introducton}

The service sector has become very significant, particularly in the developed world economies. At the end of the $20^{\text {th }}$ century over $60 \%$ employees were engaged in the service sector in the most developed market economies. This percentage is even higher nowadays, naturally in favour of service industry [1]

Structural changes and the increasing tendencies of the role of service industry are present on a global scale. The significance and role of service industry keeps increasing in the developed, but also in the developing countries. It is indicated more and more often that the modern society has been taken over by the domination of services, terms such as "service economy" or "service society" have been introduced. The growing significance of service industry is evident in its increasing contribution to building the social product.

Pursuant to the growing significance of quality in modern business operation, Quality of service is established as a priority for organizations wishing to differentiate their services in the highly competitive environment. Two trends have generally been present: services have become a dominant sector in the economy of the highly developed countries and the offered products are at the same time more and more often a combination of products and services as an answer to the increasing understanding of user needs.

From a scientific perspective, Quality of service is frequently a topic in modern management theory and practice. Marketing researchers have significantly contributed to the understanding of the nature of services and the nature of user satisfaction. The following hypothetical views on Quality of service is considered in last decades:
- it is more difficult for users to assess Quality of service as compared to product quality,

- perceptions of Quality of service are the result of users' comparison of their expectations with the actually performed services,

- Quality of service performances assesment comprise working characteristics of the product during the life cycle, but also the quality of logistic support operations comprising service activities related to their maintenance and

- quality assessment is not only based on the outcome of the service process, but includes also an evaluation of the delivery process itself.

The automotive industry has recognized the previously mentioned fact that in order to meet growing customer demands there is a need to offer services together with their products and they implement the services into their core offering. Services in the focus of present research are after-sales vehicle maintenance services, where we wanted more specifically to determine factors that best represent their quality. All the research shows that those services are of great importance for the automotive industry.

\section{Theoretical background of the subject of research}

In modern business operation conditions where "focus is on users", Quality of service has become a priority for service organizations. In other words, the quality of delivered services is recognized as having such significance for business operation that its concept is requested not only for the purpose of achieving success, but also in some cases, in order to survive on the market. Quality of service achievement and maintenance, based 
on the principle of understanding user expectations, is believed to be the basic strategy for successful provision of user satisfaction and their retention $[2,3]$.

Although automotive industry is popular for research in the field of operative management, the automotive service industry is not often mentioned. Activities related to vehicle maintenance belong to service industry and the entire set of these activities is desribed in literature by the common term of after-sales services. After-sales services may also be defined as "all initiated activities in the direction of providing vehicle quality and reliability, undertaken after users take over their vehicles in the aim of providing user satisfaction" [4].

The main reasons for inclusion of after-sales services into basic product offer could be divided into three categories: after-sales economy, user demands and competitive advantage [5].

Firstly, the after-sales services market is considered, from the economic point of view, in some industries as a four to five times greater market than the market of the products themselves. Some authors indicate that aftersales could generate a three times greater turnover than the sales themselves.

On the other hand, the continuous increase of user demands with respect to services, induces manufacturers to provide value added services and to leave support processes to outsourcing, achieving thereby greater flexibility and efficiency.

The third significant reason is the gain of competitive advantage. After-sales services represent a source of profit in the context of global competition and reduced profits from product sales, and thus they are also the differentiation key for manufacturing companies. Some authors even indicate after-sales as a way to cover losses in profit due to sales prices, which have to be reduced, because of enormous competition.

Automotive manufacturers have included after-sales services in their basic product offer. These services include: instructions for use, automotive maintenance, spare parts delivery, warranties, etc. [6]. One of the slogans, which may be frequently heard in automotive dealerships, is that it is the sales department that sells the first car and the after-sales department that sells every following one.

However, quality is an abstract concept in service industry, thus also in after-sales services and it is therefore difficult to define and measure it. The specific properties of services must be considered and understood properly in order to understand the quality concept in service industry. Many researchers believe that quality is based in customer perception on a long-term, cognitive company evolution, whereas satisfaction is a short-term, emotional reaction to a specific experience with a delivered service. Research has been conducted in service industry in the aim of generalizing a model for Quality of service assessment. The SERVQUAL model is the result of such efforts, according to which Quality of service is evaluated through a five dimensional concept: reliability, assurance, tangibles, empathy and responsiveness. SERVQUAL has found supporters among a large number of authors and has been applied, with certain modifications, in many service industries [7].
However, just as it had its supporters, this model has also been subject to a lot of criticism from the moment of its formation. Another approach to Quality of service measurement has been formulated and consolidated in the SERVPERF model [8], in the aim of disputing the basis on which the SERVQUAL model was formed, in which measure of quality is based on expectation-perception gap. SERVPERF model advocates the use of direct performance measures at the moment of service delivery as better quality measurement approach. Furthermore, many scientists believe that it is not possible to introduce a uniform scale for quality measurement in all service industries and that the number and kind of dimensions should instead be adjusted to specific service contexts [9].

The approach enabling better quality assesment by means of performance measurement in service industry is used in this study. In order to fulfill the research task it is necessary to empirically and accurately identify key quality indicators and factors for assessment of performed services from customer perspective and to determine their significance. Using such findings managers in automotive service stations, as in all other organizations, may focus their attention on the segments of the greatest importance to users and thus define the priorities for further advancement $[10,11]$. This is exactly what has been done and the results are presented in this paper.

The importance of this research can be also verified from the point of the fact that many organizations today measure customer satisfaction and use it with other indicators of business performance for making future management decisions. Thus, the frequently used framework in practice, the BSC (Balanced Scorecard)[12], classifies the business operation success indicators into four groups: financial perspective, internal processes, learning and growth and customer perspective, including also measurement of their satisfaction. As researchs shows Quality of service is the base of customer satisfaction. It is believed that all perspectives are important and that only organization management approaches, which include all these four segments, may lead to long-term success.

\section{Research method}

The selection of research method was determined by the nature of the subject of research. Special scientific methods have also been used in the subject research, besides general scientific methods.

General scientific methods are immanent in all scientific knowledge acquisition, thus also in this research. The statistical method was the dominant one among the general scientific methods used in the research [13].

The descriptive "survey-research" method was used among the special research methods, since this form of scientific description entails an active inclusion of respondents in giving information about phenomena, which are the subject of research, based on which it is possible to get to the essence of the subject of research and determine its state, and also discover the cause and effect relationship. However, this does not mean that the use of other research methods had been entirely ignored; on the contrary, in order to be able to answer all questions 
designated in the subject research, it was also necessary to apply theoretic and historic methods, making thus the subject research more comprehensive and reliable.

The following research techniques were used in the practical realization stage of the research:

- questionnaire technique, for collecting data on users of automotive service stations i.e. on their social (gender, age) and andragogy (education level) features, and - scaling technique, for evaluating specific aspects of offered services in automotive service stations by users.

\section{Research results}

In order to define quality factors, which was the basic goal of the subject research, it was necessary to firstly define quality determinants i.e. indicators [14].The system for measuring quality indicators for offered services in automotive service stations, represents a set of metric information, from the aspect of customer perspective, used to quantify service effectiveness and efficiency. In order to properly define this system, it was necessary to pay special attention to indicator validity, objectiveness, reliability and accuracy.The methodological procedure for validity determination was validation by knowledge [15].

\subsection{The research procedure}

The procedure of the research is presented in flow diagram, Fig. 1. Detailed description is also shown in following paragraphs.

First of all an initial list of quality indicators for automotive station services was completed, based on the opinion of automotive station service users and providers.

Explanation was given to users of a given automotive station services about what quality of work perfomance in automotive service stations entails, and then 63 of them were asked to write down on a sheet of paper, their opinion of all the individual aspects of the offered services which could describe the quality of work performed in automotive service stations. The same was asked from 14 service providers in automotive service stations. Based on the defined quality indicators for services provided by automotive service stations, a scale was comprised of opinions on the individual aspects of offered services in automotive service stations (48 items), which was used for a sample of 64 respondents - users of automotive services. The task was to express their agreement with the statements (individual quality aspects of the quality of provided services) on a Likert scale from 1 to 5. It was determined on the basis of the data collected in this way, that some items were not clear enough, while others were not offering what was expected of them. For this reason 6 of them were excluded from this instrument.

The final version of the scale was defined following consultations with experts (providers of automotive station services with the highest professional qualifications and longest work experience). They excluded the other three items from the opinion scale, so that there are 39 items in the final version.

The indicator validity was also confirmed by statistical analysis of variables in the opinion scale, defined on the basis of previously defined indicators. The obtained communalities range from medium to high values, i.e. from 0,597 to 0,827 , whereby validity of the defined indicators had been confirmed.

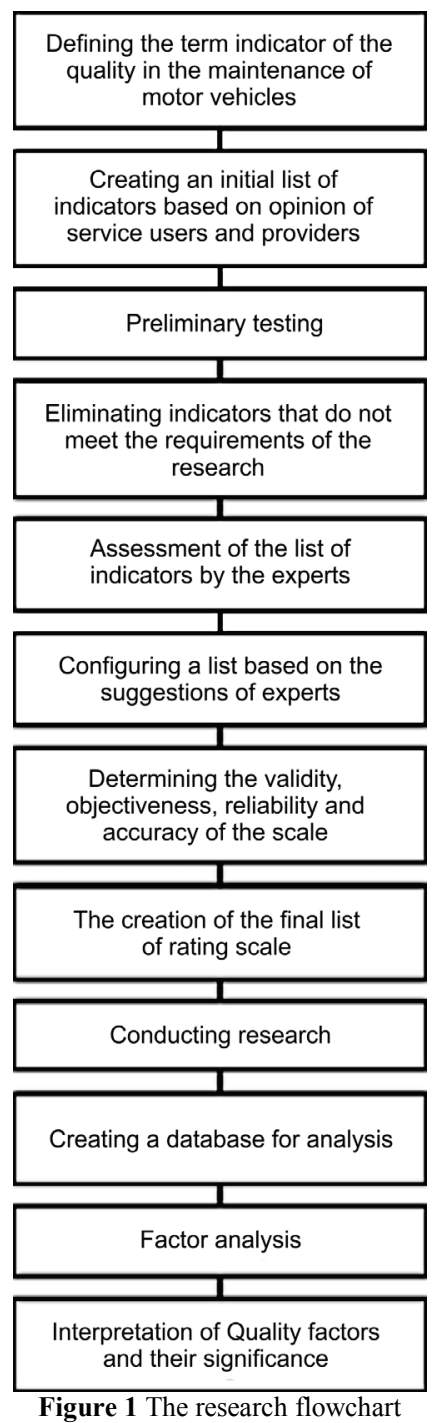

Indicator objectivity was secured by the manner in which the list of indicators was comprised and later by their use within the opinion scale, by which respondents expressed their evaluation of the individual quality aspects of the offered services (on a rating scale of 1 to 5). Such approach to indicators and opinion scale, constructed on their basis, eliminated any possible doubt about biased conduct of researchers.

Accuracy which is also required to provide scientific basis to indicators was provided by strict and careful definition of the meaning of the individual indicators, whereby the necessary requirements were established for the determination of significant and often difficult to perceive nuance manifestations of certain quality variables of offered automotive station services.

Conducted methodological procedure leads to the definition of 39 quality indicators for automotive station services from customer perspective:

1) staff responsiveness to customers,

2) staff kindness,

3) effort to find out as much as possible about customers,

4) adjusting time schedules for execution of works on vehicles to customer requirements and wishes, 
5) reminding customers of service appointments,

6) prompt telephone call answering by responsible persons,

7) respect of appointments,

8) pleasant atmosphere at service stations,

9) staff conduct at service stations inciting confidence,

10) competence for giving answers to posed questions,

11) expressed interest and readiness to solve customer problems,

12) opting for the most acceptable solutions for customers,

13) service receptionists attentively take note of customers' comments on cars,

14) service receptionists describe to customers the works to be performed on cars,

15) service receptionists explain to customers the reasons for the anticipated works on cars,

16) promptness of information on the completion of works on cars,

17) customers get information on the prices of anticipated works,

18) customer consent is requested for additional works,

19) unnecessary works on cars are avoided,

20) service departments make an effort to complete works within agreed time frames,

21) performed works on cars are good quality and do not require rework,

22) customers are given replacement cars to use until completion of works on their own cars,

23 ) customers get advice about how to make best use of their cars,

24) adequate and tidy work clothes for staff,

25) tidiness of service station premises,

26) attractiveness of service station advertising material,

27) available parking place for service station customers,

28) clear direction markings for customer orientation,

29) pleasant ambiance where customers wait for comletion of servicing works,

30) written assurance of completed quality control of performed works,

31) delivery of clean cars to customers,

32) service receptionists deliver cars to customers,

33) respect of working hours,

34) car delivery to customers even after working hours,

35 ) it does not take long to prepare documents for performed services,

36) transparent and clear invoices,

37) invoices are explained to customers,

38) collecting feedback information on customer satisfaction with offered service and

39) Quality of service at service stations has an impact on the purchase of a a specific vehicle brand.

The reliability of the opinion scale was determined by classic summary methods and ranged from 0,8843 to 0,9449 , as follows:

a) Cronbach's Alpha coefficient $=0,9395$;

b) Guttman Split-halfcoefficient $=0,8843$;

c) Guttman coefficient:

$\begin{array}{lll}\text { Lambda } 1= & \text { Lambda } 2= & \text { Lambda } 3= \\ 0,9154 & 0,9449 & 0,9395 \\ \text { Lambda } 4= & \text { Lambda } 5= & \\ 0,8843 & 0,9291 & \end{array}$

It has been determined based on the obtained reliability coefficients that the used instrument has a very high reliability and internal scale agreement for the used sample considering the number of items, covered by it and could therefore be used in the subject research.

Besides having social-andragogy features, the obtained indicators have been included in the Questionnaire given to customers to fill in. The sample used in the research consisted of customers who were direct users of automotive station services. A total of 146 people were questioned. Testing was done in authorised services of the following car manufacturers during year 2012: BMW, Audi, Toyota, Volkswagen, Škoda, and Citroen. Customes were asked to fill-in the Questionairre when taking their car after the service work was done. After all data were collected, factor analysis was then used to ensure reliable identification of the quality factors which objectively express customer satisfaction with services performed. Thus, all manifest variables indicators were summarized to a smaller number of latent variables - factors, based on mutual relation and according to predetermined mathematical-logic conditions. Considering that an inter-correlation matrix of all manifest variables forms a starting basis for quality factor definition, it was necessary to subject it to significance tests in order to verify justification of the used factor analysis. A sampling adequacy index was obtained thereby, amounting to 0,777 [16], which was considered a very good indicator. The value of Bartlett's Test of Sphericity was also high $(r=0,000)$, representing a reliable basis for the use of factor analysis (see Tab. 1).

Table 1 Tests of statistical significance of the correlation matrix for Factor analysis

Kaiser-Meyer-Olkin "Sampling Adequacy Index" $\quad 0,862$

\begin{tabular}{l|l|l} 
Bartlett's Test of & Approximation Chi-square test & 3391,956
\end{tabular}

\begin{tabular}{l|l|c} 
Sartlett's Test of & Number of degrees of freedom & 741
\end{tabular}

To ensure higher realiability of applied method Cattell "Scree" Test was also used. The essence of this test makes a graphical representation of characteristic roots in order of their separation and identification of the turning point after which the curve becomes a straight line. Ordinal number corresponding to that point, suggests the number of factors that needs to be kept in further analysis.

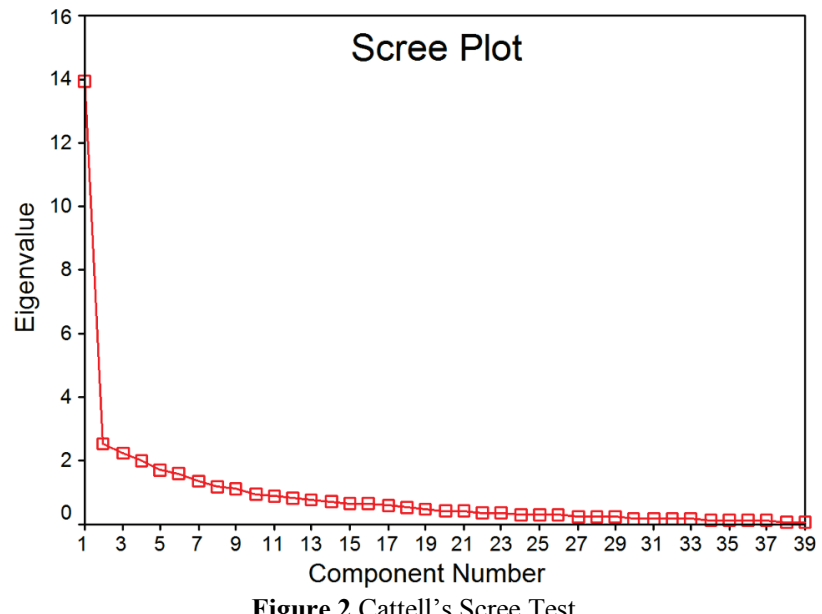


Thus, factor analysis, with the use of Cattell's Scree Test, undoubtedly points out to a nine factor solution, i.e. that nine factors of satisfactory quality of performed automotive station services have been singled out from customer perspective, representing all 39 manifest variables - quality indicators for performed services.

The eigenvalues for these nine factors are:13,939; 2,$531 ; 2,239 ; 2,027 ; 1,717 ; 1,565 ; 1,360 ; 1,192$ and 1,093 (see Fig. 2). They cover $70,933 \%$ of the cumulative proportion of total variance.

\subsection{Automotive service station Quality of service factors}

Tab. 2 shows factor configuration and factor structure matrices of the Quality of services performed in automotive service stations from customer perspective, based on which quality factors were defined. Only those quality indicators for performed services with a factor weight value above 0,3 and which were in correlation with factors above 0,3 have been taken into consideration here [17]. However, some of the indicators which had factor weight values and/or coefficients of correlation with those factors smaller than 0,4 are not presented in the text below.

Factor \#1 is mostly defined by indicators (manifest variables) related to assurance of automotive service station capability to provide the promised services in an appropriate manner. As Tab. 2 shows, this factor is determined by the following quality indicators for performed services: (1) responsible individuals promptly answer telephone calls $(6 / 0,814 ; 0,807$-the first number is the number of the indicator in the Questionnaire, the second number indicates the weight factor, and the third is the correlation coefficient of the variables and factors), (2) service departments respect appointments for works to be performed on cars $(7 / 0,808 ; 0,791)$, (3) customers get timely information about when works will be completed on their cars $(16 / 0,755 ; 0,734)$, (4) customers do not wait long at vehicle delivery for preparation of documents related to performed services $(35 / 0,715 ; 0,799)$, (5) staff conduct at service stations gives assurance to customers $(9 / 0,709 ; 0,774),(6)$ service station staff respects the prescribed working hours $(33 / 0,605 ; 0,705)$, (7) service departments make an effort to complete works within the agreed time frame $(20 / 0,579 ; 0,682),(8)$ the performed works on cars are good quality and there is no need for rework $(21 / 0,564 ; 0,639)$, (9) service station staff has the knowledge and experience to answer all customer questions $(10 / 0,551 ; 0,681),(10)$ the atmosphere at the service station is pleasant $(8 / 0,468 ; 0,647)$ and (11) service stations have available free parking space for customers $(27 / 0,467 ; 0,609)$.

All of the above mentioned indicators have a significant projection on the first factor and indicate that their impact is primarily directed towards assurance of automotive service stations users of the automotive service stations staff's readiness to always provide them with assistance and appropriate quality. It is possible, based on this, to define the first factor as Reliability (capability of delivering requested services in a satisfactory manner). This finding is also in agreement with earlier research. The earlier mentioned SERVQUAL scale singled out this factor in its five dimension concept [7].
Factor \#2 is mostly defined by the following indicators: (1) service stations offer replacement cars - cars which customers may use while works are performed on their own cars $(22 / 0,757 ; 0,776),(2)$ cars may be delivered to customers even after working hours $(34 / 0,730 ; 0,635)$, (3) service departments contact customers to find out whether they are satisfied with the offered services $(38 / 0,721 ; 0,818),(4)$ service departments contact customers to remind them of servicing appointments $(5 / 0,440 ; 0,652)$ and $(5)$ service station employees make an effort to get to know customers better $(3 / 0,418 ; 0,621)$.

This factor may be defined, considering the above mentioned indicators, as Special features. Earlier research confirms also the singling out of this factor. Thus, David A. Garvin in his definition of product quality dimensions from consumer perspective, included also Special Features among eight of the most significant ones [18]. They refer to properties which make basic product functions complete.

Factor \#3 is defined by quality indicators for performed services indicating readiness of automotive station service providers to provide assistance to customers. The most significant among these are: (1) service station staff expresses interest and readiness to solve customer problems $(11 / 0,764 ; 0,835)$, (2) service receptionists listen carefully to customer comments related to cars $(13 / 0,761 ; 0,827)$, (3) service receptionists explain to customers why repair works are required $(15 / 0,748 ; 0,716),(4)$ responsible staff at service stations takes into account customers' interests when proposing problem solution and suggests the best solution for customers $(12 / 0,694 ; 0,774)$, (5) customers always get good advice for using their cars $(23 / 0,535 ; 0,713)$ and $(6)$ unnecessary works on cars are avoided at service stations $(19 / 0,481 ; 0,680)$.

It is possible to see, once all factor elements have been analysed, that they are directed towards showing responsiveness and empathy to customers. Therefore, there are good reasons to designate it as Responsiveness and empathy. Furthemore, one of the general principles of business ethics is also based on the recognition of and experience with the above mentioned, indicating that candour, openess, truthfulness, keeping promises and transparency contribute to facility and efficiency of business transactions [19].

Factor \#4 is mostly represented by the following quality indicators for performed services: (1) customers get transparent and clear invoices $(36 / 0,829 ; 0,783),(2)$ if additional works are required, service station staff contacts customers to request consent $(18 / 0,696 ; 0,743)$, (3) competent service station staff explains invoices to customers $(37 / 0,482 ; 0,673)$ and (4) performed works on cars are good quality and there is no need for rework $(21 / 0,468 ; 0,612)$.

Fourth factor is defined by manifest variables, pointing out provision of truthful information about performed services. Therefore, the subject factor may be defined as Transparency. Transparent systems have clear procedures for making decisions of interest to automotive station service users and for open communication with them [20]. 
Table 2 Configuration and Structure Matrices

\begin{tabular}{|c|c|c|c|c|c|c|c|c|c|c|c|c|c|c|c|c|c|c|}
\hline \multirow{2}{*}{$\begin{array}{l}\text { Performed } \\
\text { services } \\
\text { quality } \\
\text { indicators }\end{array}$} & \multicolumn{9}{|c|}{ CONFIGURATION FACTORS } & \multicolumn{9}{|c|}{ STRUCTURE FACTORS } \\
\hline & I & II & III & IV & V & VI & VII & VIII & IX & I & II & III & IV & $\mathrm{V}$ & VI & VII & VIII & IX \\
\hline 1. & 0,392 & $-0,113$ & 0,159 & & 0,109 & 0,400 & & 0,084 & 0,019 & 0,658 & 0,222 & 0,550 & 0,207 & 0,460 & 0,624 & 0,355 & $-0,072$ & 0,115 \\
\hline 2. & 339 &, 175 & 0,262 & 0,102 & 158 & 0,185 & 0,068 & $-0,151$ & 0,413 & 0,605 & & & & 0,489 & & 0,224 & & \\
\hline 3. & 164 & 0,418 & 0,279 & $-0,022$ &, 099 & 0,063 & 0,115 & $-0,110$ & 0,267 & 0,552 & 0,621 & 0,613 & 0,326 & 0,228 & 0,340 & 0,378 & & \\
\hline 4. & 247 & $-0,006$ & 0,082 & 0,137 & $-0,020$ & $-0,025$ & 0,012 & $-0,267$ & 0,773 & 0,433 & 0,169 & 0,458 & 0,308 & 0,236 & 0,225 & 0,106 & $-0,178$ & 0,779 \\
\hline 5. &, 046 & 0,440 & 0,293 & $-0,129$ & $-0,111$ & 0,122 & 0,430 & $-0,129$ & $-0,015$ & 0,427 & 0,652 & 0,535 & 0,240 & 0,196 & 0,330 & 0,619 & & 0,000 \\
\hline 6. & 814 & $-0,033$ & $-0,076$ & 0,170 & $-0,212$ & 0,011 & 0,124 & $-0,030$ & 0,133 & 0,807 & 0,318 & 0,438 & 0,390 & 0,106 & 0,306 & 0,358 & $-0,080$ & 0,177 \\
\hline 7. & & & 0,132 & $-0,133$ & 0,100 & & & & & 0,791 & & 0,513 & 0,158 & 0,303 & 0,187 & & & \\
\hline 8. & 468 & $-0,055$ & 0,012 & 0,331 & 0,255 & 0,027 & $-0,118$ & $-0,120$ & 0,160 & 0,647 & 0,244 & 0,513 & 0,522 & 0,498 & 0,439 & 0,151 & $-0,234$ & 0,240 \\
\hline 9. & 709 & & $-0,010$ & & & 226 & & & & 0,774 & & 19 & 0,542 & 0,277 & 0,202 & & & 0,172 \\
\hline 10. & & & 0,394 & & & & & & & & & & & & 0,275 & & & \\
\hline 11. & 386 &, 017 & 0,764 & 0,184 & 022 & $-0,178$ & 0,026 & 0,050 & $-0,062$ & 0,683 & 0,330 & 0,835 & 0,204 & 0,340 & 0,235 & 361 & 17 & 52 \\
\hline 12. & & & & & & & & & & & & & & & & & & \\
\hline 13. & 186 & 0,007 & 0,761 & 0,114 & 0,079 & $-0,017$ & $-0,297$ & 0,175 & $-0,004$ & 0,556 & 0,303 & 0,827 & 0,409 & 388 & 0,336 &, 092 & 66 &, 242 \\
\hline 14. & 059 & $-0,498$ & 0,265 & & 295 & & 0,334 & & & 0,346 & & 0,501 & & & & & & \\
\hline 15. &, 122 & 0,012 & 0,748 & 0,089 & 011 & 118 & 0,074 & 0,413 & $-0,241$ & 0,346 & 0,318 & 0,716 & 0,358 & 0,284 & 0,278 & 0,380 & 0,308 & $-0,008$ \\
\hline 16. & & & 0,070 & & $-0,060$ & & & & & 0,734 & & 0,455 & 0,250 & 0,134 & & & & 0,050 \\
\hline 17. & 096 & 0,080 & 0,283 & $-0,041$ & 0,323 & $-0,180$ & 0,334 & 0,441 & 0,020 & 0,176 & 0,251 & 0,402 & 0,133 & 0,343 & $-0,042$ & 0,496 & 0,474 & 0,168 \\
\hline 18. & 265 & 0,003 & 0,218 & 0,696 & 382 & $-0,105$ & $-0,027$ & 0,073 & & 0,153 & 29 & 0,463 & 0,743 & 0,475 & 0,187 & 201 & 04 &, 145 \\
\hline 19. & 059 & 0,377 & 0,481 & 0,279 & 115 & &, 159 & & $-0,0$ & 0,499 & & 0,680 & 0,562 & 0,211 & 0,363 & & 56 &, 081 \\
\hline 20. & 579 & 0,107 & 0,278 & 0,141 & 107 & & & 58 & 0,181 & 0,682 & & 0,570 & 0,145 & 0,184 & 12 & 80 & & 0,349 \\
\hline 21. & & & & & & & & & & & & & 0,6 & 055 & & & & \\
\hline 22. & 052 & 0,757 & 0,031 &, 010 & & & & & & 0,295 & 0,776 & 0,332 & 0,251 & 0,149 & & 325 & & 0,074 \\
\hline 23. & & & & & & & & & & & & & 0,501 & 0,226 & 56 & & & 0,262 \\
\hline 24. & 104 & 0,033 & $-0,124$ & 0,024 & 0,866 & $-0,088$ & 43 & 0,110 & & 0,327 & & 0,331 & 0,190 & 0,838 & 0,275 & & 38 &, 212 \\
\hline 25. & 032 & 0,198 & 0,031 & 0,200 & 821 & $-0,073$ & $-0,209$ & 0,041 & 0,032 & 0,295 & & & 0,368 & 0,820 & 30 & 70 & & 0,147 \\
\hline 26. & & & 0,013 & & & & & & & 0,585 & & & 0,169 & 0,443 & & & 63 & $-0,254$ \\
\hline 27. & 467 & 0,051 & $-0,231$ & 0,134 & 209 & 0,256 & 0,118 & $-0,129$ & $-0,258$ & 0,609 & 0,320 & 0,286 & 0,345 & 0,432 & 0,557 & 0,322 & $-0,318$ & $-0,255$ \\
\hline 28. & & & $-0,119$ & $-0,015$ & & & & & & 0,358 & & 0,307 & 0,218 & 0,502 & 0,708 & & 099 & $-0,035$ \\
\hline 29. &, 140 & $-0,003$ & 0,004 & 0,118 &, 281 & 0,998 & 0,091 & 0,133 & 0,072 & 0,263 & 0,196 & 0,284 & 0,283 & 0,141 & 0,821 & 0,159 & $-0,084$ & 0,065 \\
\hline 30. & 023 & 0,011 & $-0,155$ & \begin{tabular}{|l|l|}
$-0,016$ \\
\end{tabular} & $-0,012$ & 0,127 & 0,900 & $-0,102$ & 0,131 & 0,320 & 0,296 & 0,253 & 0,201 & 0,199 & 0,222 & 0,856 & $-0,033$ & 0,055 \\
\hline 31. & 330 & $-0,033$ & 0,315 & $-0,125$ & $-0,009$ & 0,000 & 0,421 & 0,091 & $-0,174$ & 0,569 & 0,312 & 0,538 & 0,183 & 0,254 & 0,252 & 0,613 & 0,055 & $-0,072$ \\
\hline 32. & 0,047 & 0,024 & 0,207 & & 0,059 & 0,228 & $-0,198$ & 0,777 & $-0,159$ & 0,232 & 0,209 & 0,351 & 0,404 & 0,172 & 0,204 & 0,099 & 0,611 & 0,053 \\
\hline 33. & 0,605 & $-0,008$ & 0,043 & $-0,132$ & 0,122 & 0,388 & $-0,232$ & 0,015 & $-0,065$ & 0,705 & 0,228 & 0,437 & 0,142 & 0,424 & 0,649 & 0,036 & $-0,203$ & 0,026 \\
\hline 34. & & & 0,101 & & & & $-0,393$ & & & 0,206 & 0,635 & 0,301 & 0,149 & 0,266 & 0,203 & $-0,078$ & 0,115 & 0,184 \\
\hline 35. & 0,715 & $-0,037$ & $-0,031$ & $-0,031$ & $-0,036$ & 0,302 & $-0,075$ & $-0,013$ & 0,106 & 0,779 & 0,256 & 0,453 & 0,234 & 0,305 & 0,564 & 0,168 & $-0,162$ & 0,170 \\
\hline 36. & 0,188 & $-0,078$ & $-0,153$ & 0,829 & 0,014 & 0,103 & $-0,102$ & 0,279 & 0,052 & 0,325 & & 0,269 & 0,783 & 0,166 & 0,234 & 0,125 & 0,158 & 0,129 \\
\hline 37. & $-0,200$ & 0,157 & 0,132 & 0,482 & 0,017 & 0,240 & 0,350 & $-0,018$ & $-0,039$ & 0,321 & 0,460 & 0,489 & 0,673 & 0,308 & 0,424 & 0,536 & $-0,098$ & $-0,010$ \\
\hline 38. & & 0,721 & $-0,033$ & 0,046 & 0,048 & $-0,071$ & 0,167 & $-0,006$ & 0,029 & 0,441 & 0,818 & 0,383 & 0,335 & 0,206 & 0,192 & 0,454 & $-0,007$ & 0,039 \\
\hline 39. & $-0,113$ & 0,413 & $-0,353$ & $-0,081$ & 0,332 & 0,058 & 0,203 & 0,165 & 0,658 & 0,071 & 0,347 & 0,079 & 0,025 & 0,311 & 0,079 & 0,233 & 0,256 & 0,619 \\
\hline
\end{tabular}

Factor \#5 is not a single meaning one. However it is mostly represented by indicators related to staff and premise tidiness: (1) service station staff is properly dressed and tidy $(24 / 0,866 ; 0,838)$ and (2) service premises are clean and tidy, $(25 / 0,821 ; 0,820)$, Tab. 2 .

This factor is defined as Visual impression. This result has also been confirmed by earlier findings about Quality of service dimensions [7,21].

Factor \#6 is mostly represented by the following quality indicators for performed services: (1) plesant area where customers can wait for completion of services (29/0,998; 0,821), (2) clear direction markings for customer orientation $(28 / 0,635 ; 0,708)$ and (3) service station staff pays equal attention to all customers $(1 / 0,400 ; 0,624)$.

Above mentioned indicators are contributed to the comfort of service users, to which we can also add the time of service delivery from the aspect of respect of working hours of staff and duration of motor vehicles delivery, Tab. 2. Pursuant to this, it is possible to define this factor as Comfort. Similar results have also been obtained in earlier studies. Johnston mentions comfort as a quality dimension in his study [22].

Factor \#7 is represented by the following quality indicators for performed services: (1) customers get written assurance that quality control of performed works has been effected $(30 / 0,900 ; 0,856)$, (2) service departments contact customers to remind them of servicing appointments $(5 / 0,430 ; 0,619)(3)$ clean cars are delivered to customers following performed works $(31 / 0,421 ; 0,613)$, (4) competent service station staff explains invoices to customers $(37 / 0,350 ; 0,536)$ and (5) service station receptionists describe to customers the works to be performed on vehicles $(14 / 0,334 ; 0,417)$.

Based on the expressed influence of the above mentioned variables, it is possible to define this factor as Confidence and assurance. This result has also been obtained in some earlier research, as is the case in the research of Bouman M. and van der WieleT. [23]. Namely, they dealt with the issue of Quality of service in automotive service stations and defined thereby three key factors: staff kindness, tangible elements and confidence, with which the subject findings are in agreement.

Factor \#8 is associated with the following quality indicators for performed services: (1) service station receptionists deliver vehicles to customers following performed works $(32 / 0,777 ; 0,611)$, (2) customers are informed about the price of the agreed works $(17 / 0,441$; 0,474), (3) service station receptionists explain to customers why repair work is required $(15 / 0,413 ; 0,308)$ 
(4) customers get timely information about when works will be completed on their vehicles $(16 / 0,400 ; 0,338)$ and (5) service stations have available attractive advertising material $(26 /-0,341 ;-0,463)$.

It can be seen that the eighth factor is mostly defined by Quality of service indicators related to communication. It is possible for this reason to define this factor as Communication. Singling out this factor is quite understandable, since success in business operation is largely determined by the quality of the relationship between service providers and users [7, 20, 22]. However, the indicator related to attractive advertising material was in negative correlation with this factor. The reason for this could be an insufficient or inadequate use of automotive service station advertising material. It is thus possible to look here for possibilities for improvement of service station communication with customers.

On the ninth factor for the quality of performed services in automotive service stations from customer perspective the following manifest variables have the greatest influence: (1) receptionists try to fulfill customer requirements when making appointments for works to be performed on vehicles $(4 / 0,773 ; 0,779),(2)$ the quality of services provided by service stations influences customer decisions to buy a certain vehicle brand $(39 / 0,658 ; 0,619)$ and (3) service station staff is kind to customers $(2 / 0,413$; 0,495).

Quality indicators for services performed in automotive service stations, which explain the ninth factor, such as promptness, incentive aspect of Quality of service and staff kindness, are in agreement with the above mentioned.Thus, this factor can be defined as Additional service dimension. It comprises indicators that are also important for full customer satisfaction.

Table 3 Quality factors for services performed in automotive service stations from customer perspective

\begin{tabular}{|c|l|c|c|}
\hline & Factor description & $\begin{array}{c}\text { Percentage of } \\
\text { explained total } \\
\text { variance }\end{array}$ & $\begin{array}{c}\text { Cumulative } \\
\text { proportion of } \\
\text { total variance }\end{array}$ \\
\hline 1 & Reliability & 35,741 & 35,741 \\
\hline 2 & Special features & 6,490 & 42,232 \\
\hline 3 & $\begin{array}{l}\text { Responsiveness } \\
\text { and empathy }\end{array}$ & 5,741 & 47,972 \\
\hline 4 & Transparency & 5,198 & 53,170 \\
\hline 5 & Visual impession & 4,402 & 57,572 \\
\hline 6 & Comfort & 4,012 & 61,584 \\
\hline 7 & $\begin{array}{l}\text { Confidence and } \\
\text { assurance }\end{array}$ & 3,488 & 65,073 \\
\hline 8 & Communication & 3,057 & 68,129 \\
\hline 9 & $\begin{array}{l}\text { Additional service } \\
\text { dimension }\end{array}$ & 2,803 & 70,933 \\
\hline
\end{tabular}

Therefore, quality factors for performed services in automotive service stations from customer perspective have been identified by factor analysis. It is necessary to mention hereby that all identified factors are not of the same significance (Tab. 3). Namely, all nine quality factors for performed services in automotive service stations explain, from customer perspective, the total variance of $70,933 \%$. It has been found that the first factor - Reliability is of particular significance, having a share of $35,741 \%$ in the interpretation of the total variance. It is justified to say that this is the key factor, since customers always count on automotive service stations which are capable of delivering requested services in a satisfactory manner.

The following five factors have quite a smaller, but not negligibly small share of the explanation of total variance. They refer to Special features $(6,490 \%)$, Responsiveness and empathy (5,741\%), Transparence $(5,198 \%)$, Visual impression $(4,402 \%)$ and Comfort $(4,012 \%)$. The remaining three factors, although having an even smaller share of the explanation of total variance, cannot be entirely ignored in enlightening the quality of services performed in automotive service stations from customer perspective.

Those are factors which refer to Confidence and assurance $(3,488 \%)$, Communication $(3,057 \%)$ and Additional service dimension $(2,803 \%)$.

\section{Conclusions}

There is no doubt that quality has one of the key roles today, regardless of whether it is a question of manufacturing or service industry organizations, in securing long-term survival of any organization on the market. Considering its significance, to be able to manage quality, it is necessary to measure and assess it. Quality factors are defined in the aim of conducting this procedure. The abstract feature of the quality of services certainly makes this procedure difficult. There have been attempts in the past to make a uniform model for measuring the quality of all services. However, a large number of scientists support the approach that it is necessary to adjust such model to specific service contexts, stressing thereby the specific aspects of this kind of activities.

The subject of this research dealt with after-sales services in automotive industry. The aim was to define quality factors and detemine their significance, which has also been accomplished. Nine quality factors: reliability, special features, responsiveness and empathy, transparency, visual impression, comfort, confidence and assurance, communication and additional service dimension have been singled out in this research.The significance of each factor has also been determined and presented in the subject work.

These results are significant for all those who are engaged in automotive services, because it is possible to manage the quality of performed services by these specific factors and to determine priorities with respect to procedures for its further advancement by taking into account the significance of the obtained factors.

\section{References}

[1] Levi-Jakšić, M.; Komazec, G. Operations Menagement, Megatrend University, Belgrade, 2008. (in Serbian)

[2] Stevanović, I.; Stanojević, D.; Nedić, A. Setting the after sales process and quality control at car dealerships to the purpose of increasing clients' satisfaction. // Journal of Applied Engineering Science. 11, 2(2013), pp. 81-88.

[3] Alizadeh, A.; Kianfar, F. Developing a model for citizens' satisfaction with public sector services based on rough sets theory: a case study of Tehran municipality. // Tehnički vjesnik 20, 5(2013), pp. 795-802. 
[4] Saccani, N.; Songini, L.; Gaiardelli, P. The role and performance measurement of after-sales in the durable consumer goods industries: an empirical study. // International Journal of Productivity and Performance Management. 55, 3/4(2006), pp. 259-283. DOI: $10.1108 / 17410400610653228$

[5] Oliva, R.; Kallenberg, R. Managing the transition from products to services. // International Journal of Service. 14, 2(2003), pp. 160-172. DOI: 10.1108/09564230310474138

[6] Duboka, Č. Maintenance of Motor Vehicles.Yugoslav Society of Automotive Engineers, Belgrade, 1999. (in Serbian)

[7] Parasuraman, A.; Zeithaml, V. A.; Berry, L. L. A Conceptual Model of Quality of service and Its Implications for Future Research. // Journal of Marketing. 49, 4(1985), pp. 41-50. DOI: 10.2307/1251430

[8] Cronin, J. J.; Taylor, S. A. SERVPERF versus SERVQUAL: Reconciling Performance-based and Perceptions- Minus-Expectations Measurement of Service Quality. // Journal of Marketing. 58, 1(1994), pp. 125-131. DOI: $10.2307 / 1252256$

[9] Awan, M. U.; Mahmood, K. Development of a service quality model for academic libraries. // Quality \& Quantity. 47, 2(2013), pp. 1093-1103. DOI: 10.1007/s11135-011-9587-x

[10] Mccollin, C.; Ograjenšek, I.; Göb, R.; Ahlemeyer-Stubbe, A. SERVQUAL and the process improvement challenge. // Quality and Reliability Engineering International. 27, 5(2011), pp. 705-717. DOl: 10.1002/qre.1234

[11] Kušljić, D.; Marenjak, S. Critical PPP/PFI project success criteria for public sector clients. // Tehnički vjesnik. 20, 6(2013), pp. 947-954.

[12] Kaplan, R.; Norton, D. The Balanced Scorecard: Translating Strategy into Action. Harvard Business School Press, Boston, Massachusetts, 1996.

[13] Mihajlović, D. The Methodology of Scientific Research Programmes. Faculty of Organizational Sciences, University of Belgrade, Belgrade, 2004. (in Serbian)

[14] Spasojević-Brkić, V.; Pokrajac, S.; Dondur, N.; Josipović, S. Allocative effiency and QM factors covariate in Serbian industry. // Journal of Applied Engineering Science. 10, 4(2012), pp. 221-225.

[15] Vujević, M. An Introduction to Scientific Research. Schoolbook, Zagreb, 2006. (in Croatian)

[16] Fulgosi, A. Factor analysis. Schoolbook, Zagreb, 1988. (in Croatian)

[17] Pallant, J. SPSS Survival Manual: A step by step guide to data analysis using SPSS (version 15), Translation of the third edition - Miljenko Šućur, Micro book, Belgrade, 2009. (in Serbian)

[18] Garvin, D. A. Competing on the Eight Dimensions of Quality. // Harvard Business Review. 65, 6(1987), pp. 101109.

[19] Damnjanović, P. Business Ethics, Faculty of Business Economics and Entrepreneurship, Belgrade, 2009. (in Serbian)

[20] Kilibarda, M. Quality Management in the Logistics, Faculty of Transport and Traffic Engineering, University of Belgrade, Belgrade, 2008. (in Serbian)

[21] Kotler, Ph.; Keller, K. L. Marketing management. Upper saddle river, NJ-Prentice hall, 2006.

[22] Johnston, R. The determinants of service quality: satisfiers and dissatisfiers. // International Journal of Service Industry Management. 6, 5(1995), pp. 53-71. DOl: $10.1108 / 09564239510101536$

[23] Bouman, M.; Wiele, T. V. Measuring Quality of service in the Car Service Industry: Building and Testing an Instrument. // International Journal of Service Industry Management. 3, 4(1992), pp. 4-16. DOl: $10.1108 / 09564239210019441$

\section{Authors' addresses}

Dragana Velimirović, mr. mech. ing.

High Business School of Professional studies "Čačak", Gradski park 2, 11080 Belgrade, Serbia

E-mail:vps.draganavl@gmail.com

Čedomir Duboka, prof. dr. sc., ret.

Faculty of Mechanical Engineering, University of Belgrade, Kraljice Marije 16,11000 Belgrade, Serbia

E-mail: cduboka@eunet.rs

Predrag Damnjanović, prof. dr. sc.

Faculty of Business Economics and Entrepreneurship, Mitropolita Petra 8,11000 Belgrade, Serbia

E-mail: damjanovic.p@sbb.rs 